\title{
Long-term survival in patients with non-small cell lung cancer and synchronous brain metastasis treated with whole-brain radiotherapy and thoracic chemoradiation
}

Oscar Arrieta ${ }^{1,2,3^{*}}$, Cynthia Villarreal-Garza², Jesús Zamora ${ }^{1,4}$, Mónika Blake-Cerda ${ }^{4}$, María D de la Mata ${ }^{1,4}$, Diego G Zavala², Saé Muñiz-Hernández² and Jaime de la Garza ${ }^{1}$

\begin{abstract}
Background: Brain metastases occur in 30-50\% of Non-small cell lung cancer (NSCLC) patients and confer a worse prognosis and quality of life. These patients are usually treated with Whole-brain radiotherapy (WBRT) followed by systemic therapy. Few studies have evaluated the role of chemoradiotherapy to the primary tumor after WBRT as definitive treatment in the management of these patients.

Methods: We reviewed the outcome of 30 patients with primary NSCLC and brain metastasis at diagnosis without evidence of other metastatic sites. Patients were treated with WBRT and after induction chemotherapy with paclitaxel and cisplatin for two cycles. In the absence of progression, concurrent chemoradiotherapy for the primary tumor with weekly paclitaxel and carboplatin was indicated, with a total effective dose of $60 \mathrm{~Gy}$. If disease progression was ruled out, four chemotherapy cycles followed.

Results: Median Progression-free survival (PFS) and Overall survival (OS) were $8.43 \pm 1.5$ and $31.8 \pm 15.8$ months, respectively. PFS was $39.5 \%$ at 1 year and $24.7 \%$ at 2 years. The 1 - and 2-year OS rates were 71.1 and $60.2 \%$, respectively. Three-year OS was significantly superior for patients with NO-N1 stage disease vs. N2-N3 (60 vs. 24\%, respectively; Response rate $[\mathrm{RR}], 0.03 ; p=0.038$ ).

Conclusions: Patients with NSCLC and brain metastasis might benefit from treatment with WBRT and concurrent thoracic chemoradiotherapy. The subgroup of NO-N1 patients appears to achieve the greatest benefit. The result of this study warrants a prospective trial to confirm the benefit of this treatment.
\end{abstract}

Keywords: NSCLC, brain metastases, chemoradiotherapy, survival

\section{Introduction}

Brain metastases occur in $30-50 \%$ of patients with Nonsmall-cell lung cancer (NSCLC) and confer upon the patient a worse prognosis and quality of life [1-6]. Median survival of patients who receive supportive care and are treated only with corticosteroids is approximately 12 months [2]. Primary approaches to the treatment of brain metastases include Whole-brain radiation therapy (WBRT), surgery, stereotactic radiosurgery, or a

\footnotetext{
* Correspondence: ogar@servidor.unam.mx

'Clinic of Thoracic Oncology, Instituto Nacional de Cancerología (INCan), Mexico City, Mexico

Full list of author information is available at the end of the article

combination, which have achieved a median survival time that ranges from 6.5-10 months [7-11].

As improvements are made in the management of brain metastases, the question arises on how to manage patients with NSCLC who have solely stable brain metastatic disease and on whether treatment should be considered for the primary lung lesion. Long-term survival has been achieved in some patients who have undergone either cranial surgery or radiotherapy and aggressive thoracic management with lung tumor resection, with studies reporting 5-year survival rates between 10 and $20 \%$ [12-16]. Few studies have evaluated the role of thoracic radiation or chemoradiotherapy as definitive 
treatment in the management of patients with NCSLC and synchronous solitary brain metastasis, and some of these have shown promising results $[17,18]$. Despite these findings, the majority of patients are only offered chemotherapy or radiation therapy in a palliative manner [18].

In an effort to clarify such conflicting data and in order to identify patients who may benefit from aggressive management, we reviewed the outcome of 30 patients with either unresectable single or multiple brain metastases treated with WBRT, who were managed subsequently with definitive thoracic chemoradiotherapy.

\section{Methods}

In a retrospective review of patients treated at the Instituto Nacional de Cancerología (INCan) in Mexico City from May 2005 to March 2009, we identified 30 patients with histologically proven NSCLC and synchronous brain metastases. All patients selected for this analysis had the following characteristics: (1) synchronous diagnosis of NSCLC and brain metastasis (within 2 months of the lung primary diagnosis); (2) absence of neoplastic spread elsewhere in the body at the time of NSCLC and brain metastases detection, and (3) patients with either one unresectable lesion or multiple brain metastases, who were not candidates for surgery or stereotactic radiosurgery treated with WBRT.

Patients' hospital records and office charts were reviewed. Variables collected for analysis included age, gender, Karnofsky performance status (KPS), Radiation Therapy Oncology Group Recursive partitioning analysis (RPA) class, primary Tumor-node-metastasis staging (TNM, according to the American Joint Committee on Cancer Staging Manual, sixth edition [19]), primary histology, and number of brain metastases.

Diagnosis of brain metastases was made based on brain imaging using either Computed tomography (CT) or Magnetic resonance imaging (MRI). These studies were obtained as a routine staging procedure or in the evaluation of suspicious symptomatology. Thoracic stage and nodal status were determined by means of chest Computed tomography (CT) with or without Positron emission tomography (PET) imaging.

\section{Treatment plan \\ Whole-brain radiotherapy}

Conventional megavoltage external beam radiotherapy was administered with a linear accelerator (energy 6 $\mathrm{MV})$ or with a cobalt bomb (1.25 MV). For WBRT, two lateral opposed fields were used, covering up to $\mathrm{C} 2$ vertebral body. Dose administered was $30 \mathrm{~Gy} / 10$ fractions. Once patients received WBRT, systemic chemotherapy was started.

\section{Systemic and thoracic treatment}

Initially, two cycles of systemic chemotherapy were administered with paclitaxel $175 \mathrm{mg} / \mathrm{m}^{2}$ Intravenously (IV) $>3 \mathrm{~h}$ and cisplatin $75 \mathrm{mg} / \mathrm{m}^{2}$ IV on day 1 every 21 days. Following response assessment after the first two cycles of chemotherapy and in the absence of progression either at the primary lung tumor or Central nervous system (CNS), chemoradiotherapy was indicated.

Thoracic radiotherapy was administered with a linear accelerator (energy 6 and/or $15 \mathrm{MV}$ ), and the treatment volume for the primary tumor was based on initial diagnosis volume. The ipsilateral hilum was treated for N0$\mathrm{N} 2$ disease, while for N3, the contralateral hilum was also included. Clinical target volume (CTV) included gross tumor volume plus $2-\mathrm{cm}$ margin and the dose to the primary tumor was 60 Gy (BED).

Concurrently with radiotherapy, weekly paclitaxel 60$80 \mathrm{mg} / \mathrm{m}^{2}$ and carboplatin at a dose of AUC 2, according to Calvert, were administered. If disease progression was ruled out, four chemotherapy cycles followed, using the same schedule as that of the induction regimen.

\section{Response assessment}

Follow-up for primary disease was performed with CT, generally every 2 months. Follow-up for brain metastases was conducted by MRI, usually every 2 months. All patients were evaluated according to Response Evaluation Criteria in Solid Tumors (RECIST) criteria every two cycles: Complete response was defined as resolution of all disease, partial response constituted a $30 \%$ decrease in the sum of the longest diameter of target lesions, progressive disease was defined as $20 \%$ increase in the sum of the longest diameter of target lesions, and stable disease comprised neither sufficient shrinkage to qualify for partial response nor sufficient increase to qualify for progressive disease. Response assessment was performed before chemoradiotherapy was indicated.

\section{Statistical analysis}

For descriptive purposes, continuous variables were summarized as arithmetic means and Standard deviation (SD), and categorical variables as relative frequencies and proportions. Progression-free survival (PFS) was calculated from date of diagnosis of NSCLS until progression. Overall survival (OS) was defined as time from diagnosis of NSCLS until death or until the patient was censored at time of last follow-up. Median time to progression, median probability of survival, and 1- and 2-year survival rates were estimated by the Kaplan-Meier method. Significance value was set at $p<0.05$. SPSS software package version 17 (SPSS, Inc., Chicago, IL, USA) was employed to analyze the data.

\section{Results}

\section{Patient Characteristics}

Patient characteristics are summarized in Table 1. Median patient age at time of diagnosis was 57 years, and 
Table 1 Baseline characteristics of patients and disease

\begin{tabular}{ll}
\hline Median age (years) & $57 \pm 11.1$ \\
\hline Gender (Female) & $17(56.7 \%)$ \\
ECOG & $8(26.7 \%)$ \\
0 & $19(63.3 \%)$ \\
1 & $3(10 \%)$ \\
2 & \\
\hline Comorbidities & $4(13.3 \%)$ \\
EPOC & $3(10 \%)$ \\
Diabetes & $3(10 \%)$ \\
Hypertension & $24(80 \%)$ \\
\hline Histology & $4(13.3 \%)$ \\
Adenocarcinoma & $2(6.7 \%)$ \\
Squamous & $23(76.7 \%)$ \\
Other & $7(23.3 \%)$ \\
\hline Smoking history & \\
Yes & $16(53.3 \%)$ \\
No & $14(46.7 \%)$ \\
\hline Nodal status & $30(100 \%)$ \\
N 0-1 (n) & $3 \pm 2$ \\
N 2-3 (n) &
\end{tabular}

ECOG: Eastern Cooperative of Gynecologists; RPA: Radiation Therapy Oncology Group Recursive partitioning analysis (RPA).

$56.7 \%$ of patients were females. Smoking history was documented in $76.7 \%$ of patients. The majority of patients had an Eastern Cooperative of Gynecologists (ECOG) performance status of 0 or 1 (90\%). The most common histology was adenocarcinoma (80\%), and all patients were RPA 2 class. Twenty patients $(66.7 \%)$ were evaluated with PET CT to rule out other sites of metastatic disease. The number of brain metastatic lesions varied between 1 and 5, with a median of three CNS metastases.

\section{Response}

With regard to response after WBRT, all patients received the planned radiotherapy dose. Twelve patients (40\%) had stable disease, nine patients (30\%) achieved partial response, and nine (30\%) presented complete response. Median number of chemotherapy cycles was six. Five patients did not receive the planned cycles (17\%). When primary tumor response was assessed, 18 patients $(60 \%)$ achieved a partial response and 12 patients (40\%) had stable disease.

\section{Outcome}

Median follow-up was $10.2 \pm 2$ months. Median PFS and OS were $8.43 \pm 1.5$ months and $31.8 \pm 15.8$ months, respectively [Figures $1 \mathrm{~A}$ and $1 \mathrm{~B}$ ]. PFS was $39.5 \%$ at 1 year and $24.7 \%$ at 2 years. Fifteen patients $(50 \%)$ had

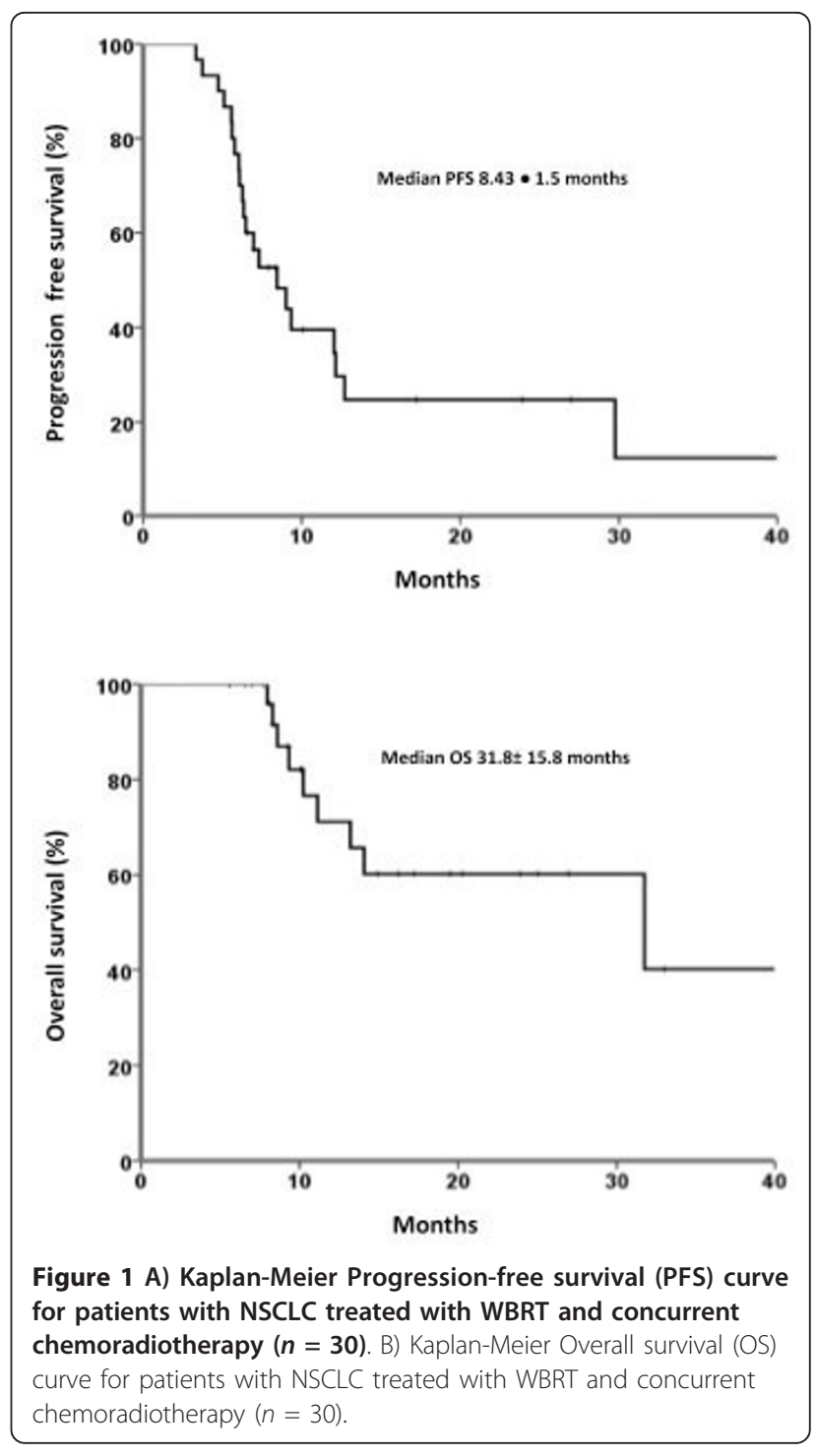

local progression, whereas 10 (33\%) developed distant sites of metastases. The 1- and 2-year OS rates were 71.1 and $60.2 \%$, respectively. Three-year OS was significantly superior for patients with N0-N1 stage disease vs. N2-N3 (60 vs. $24 \%$, respectively; RR, $0.03 ; p=0.038$ ) [Figure 2]. In a univariate analysis using the Log Rank test, there was no statistically significant difference in survival according to age $(p=0.07)$, KPS $(p=0.5)$, global response $(p=0.7)$, history of smoking $(p=0.4)$, and histology $(p=0.17)$.

\section{Discussion}

A considerable proportion of patients with NSCLC develop brain metastases at some point during their disease course and this generally leads to a poor prognosis. However, in some cases, long-term survival has been achieved after aggressive therapy of cerebral lesions, 


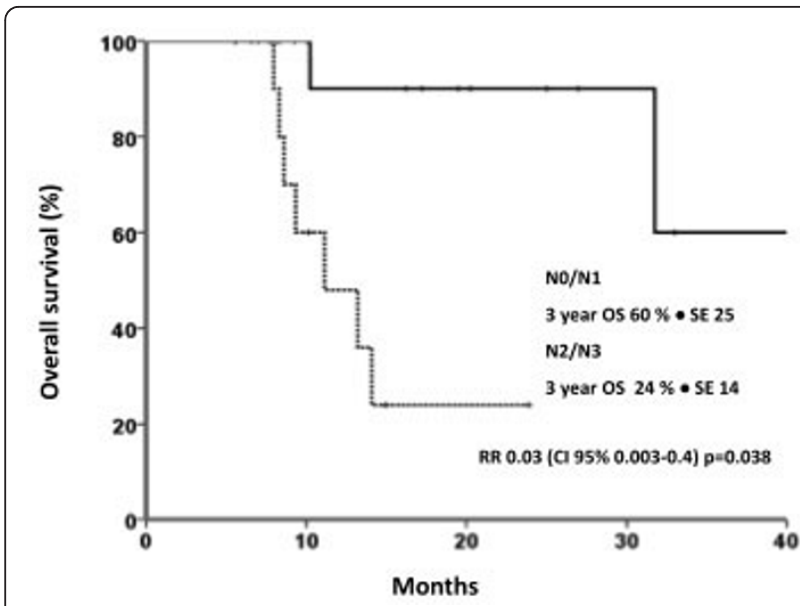

Figure 2 Overall survival (OS) for patients with NSCLC treated with WBRT and concurrent chemoradiotherapy.

with a median survival of 10-12 months and 5-year survival rates ranging from $10-25 \%[7,8,20,21]$.

As improvements are made in the management of patients with brain metastases without extracranial disease, the question arises of how to treat the primary lung cancer. This is due to the fact that the main cause of death in patients with lung carcinoma treated aggressively for brain metastases is progression of the primary cancer [13,22].

In a recent review of the literature, Modi et al. identified 11 papers that addressed the issue of surgical resection of the primary tumor within the context of metastatic brain lesions [23]. They found that median survival for curative intent groups (combined therapy with or without adjuvant treatment) ranged from 19-27 months (mean, $23.12 \pm 3.3$ months) and 1-, 2-, and 5year OS reached $56-69 \%, 28-54 \%$, and $11-24 \%$, respectively. The authors concluded that in the absence of mediastinal lymph node involvement, surgical resection of NSCLC with complete resection of the brain metastasis improves prognosis. Furthermore, they described that some features such as adenocarcinoma histology, low carcinoembryonic antigen (CEA) levels at presentation, response to preoperative chemotherapy before local treatment, and high KPS score may have a positive prognostic value.

The benefit of surgical resection after induction therapy compared with definitive radiotherapy remains uncertain and appears to be associated with an increase in early surgery-associated mortality. The Intergroup 0139 [24] and the EORTC 08941 [25] did not confirm a significant survival advantage for surgery following either neoadjuvant concurrent chemoradiotherapy or induction chemotherapy. Thus, we opted to treat our patients with NSCLC with brain metastases with definitive chemoradiotherapy as an alternative to a more aggressive surgical approach.

To our knowledge, five different studies have reported their results in patients with NSCLC with synchronous brain metastatic disease treated with radiotherapy $[13,16-18,26]$ and/or chemoradiotherapy $[17,18]$ to the primary tumor, but the majority of these studies also included patients treated with other modalities, such as surgical resection of the thoracic lesion $[13,16,18]$ or solely chemotherapy [17]. Brain management differed significantly among these series, and included surgical resection of brain metastases, WBRT, stereotactic surgery, or a combination of the former. Median OS times varied between 5.2 and 18 months, with 1 - and 2-year survival rates that ranged between $22-71.3 \%$ and 10 $34.1 \%$, respectively. For patients treated with definitive thoracic therapy after brain metastases management with gammaknife stereotactic radiosurgery, Flannery et al. reported significantly better survival than those that did not receive definitive treatment (median OS, 26.4 vs. 13.1 months). In our series, we reached a median survival of 31.8 months, the longest survival reported to date in patients with synchronous brain metastatic disease treated with definitive chemoradiation to the primary. Unlike other studies, in our report, treatment delivered to the brain, as well as systemic and local therapy, was homogeneous among all patients included.

By applying American Joint Committee on Cancer (AJCC) staging only to the primary site, $\mathrm{Hu}$ et al. reported that patients with thoracic stage I had a more favorable outcome, with a median survival time of 25.6 months (compared with 9.5 and 9.9 months for stages II and III, respectively), and concluded that aggressive treatment to the lung may be justified for newly diagnosed thoracic stage I NSCLC with a solitary brain metastasis [17]. Also, Louie et al. reported longer overall survival for stage I/II disease of 14.7 months compared with 7 months for patients with stage III NSCLC with synchronous solitary brain metastasis treated with craniotomy and WBRT [16]. In our study, according to the univariate analysis, we found that patients with N0-N1 disease had a significantly better 3-year survival rate compared with those with N2-N3 disease. Similar findings have been reported in previous studies where the absence of mediastinal lymph node involvement (N2) is one of the most important survival determinants $[15,27,28]$. Accordingly, in patients with controlled brain disease and early lung disease (N0-N1) amenable to resection, a conservative surgery of the primary tumor may be the best treatment alternative (segmentectomy or lobectomy). For patients who are not candidate for surgical resection, chemoradiatiation to the primary tumor should be considered. In Table 2, we condensed the studies that assessed radiation therapy or 
Table 2 Series evaluating radiation therapy or chemoradiotherapy of lung cancer in NSCLC with brain metastasis

\begin{tabular}{|c|c|c|c|c|c|c|c|c|c|}
\hline Study & Year & $\begin{array}{l}\text { Number of } \\
\text { patients }\end{array}$ & $\begin{array}{l}\text { Number of } \\
\text { brain } \\
\text { metastases }\end{array}$ & $\begin{array}{l}\text { Brain } \\
\text { treatment }\end{array}$ & $\begin{array}{l}\text { Median } \\
\text { survival, } \\
\text { months }\end{array}$ & $\begin{array}{l}\text { 1-year } \\
\text { survival } \\
\text { rate (\%) }\end{array}$ & $\begin{array}{l}\text { 2-year } \\
\text { survival } \\
\text { rate (\%) }\end{array}$ & $\begin{array}{l}\text { 5-year } \\
\text { survival } \\
\text { rate (\%) }\end{array}$ & Prognostic factors \\
\hline $\begin{array}{l}\text { Chidel et al. } \\
\text { [13] }\end{array}$ & 1999 & $\begin{array}{l}\text { Sx }=2 \\
\text { Sx }+ \text { RT }=3 \\
\text { RT }=8 \\
\text { Palliative = } \\
15\end{array}$ & 1 & $\begin{array}{l}\text { SX } \\
\text { WBRT } \\
\text { STS } \\
\text { and } \\
\text { combination }\end{array}$ & $\begin{array}{l}\text { Overall: } 6.9 \\
\text { Definitive tx: } \\
20.1 \\
\text { No definitive } \\
\text { tx: } 3.5\end{array}$ & & 12 (3-year) & & $\begin{array}{l}\text { WBRT } \\
\text { Aggressive thoracic } \\
\text { treatment }\end{array}$ \\
\hline $\begin{array}{l}\text { Moazami et } \\
\text { al.[31] }\end{array}$ & 2002 & $\begin{array}{l}\text { Chemo/RT } \\
=29 \\
\text { Sx }=59\end{array}$ & $\begin{array}{l}42 \text { pts: } 1 \\
49 \text { pts: }>1 \\
\text { Metachronous } \\
\text { brain lesions }\end{array}$ & $\begin{array}{l}\text { Sx } \\
\text { WBRT } \\
\text { STS } \\
\text { and } \\
\text { combinations }\end{array}$ & 5.2 & 22 & 10 & - & $\begin{array}{l}\text { Younger age } \\
\text { Stage IIIA } \\
\text { Lung resection } \\
\text { ECOG } \\
\text { No extracranial mets } \\
\text { Sx of brain mets } \\
\text { STS }\end{array}$ \\
\hline Hu et al.[17] & 2006 & $\begin{array}{l}\text { RT }=44 \\
\text { Chemo }= \\
23 \\
\text { Chemo/RT } \\
=13\end{array}$ & 1 & $\begin{array}{l}\text { Sx } \\
\text { STS }\end{array}$ & $\begin{array}{l}\text { Overall: } ~ 15 \\
\text { Stage I: } 25.6 \\
\text { Stage II: } 9.5 \\
\text { Stage III: } 9.9\end{array}$ & 49.8 & 16.3 & 7.6 & Thoracic stage I \\
\hline $\begin{array}{l}\text { Ampil et al. } \\
\text { [26] }\end{array}$ & 2007 & $\begin{array}{l}>65 \text { year } \\
\text { RT }=22 \\
\text { No RT }=50\end{array}$ & 1 & $\begin{array}{l}\text { WBRT } \\
\text { STS } \\
\text { Sx } \\
\text { and } \\
\text { combinations }\end{array}$ & $\begin{array}{l}\text { RT }=5 \\
\text { No RT }=3 \\
p=0.28\end{array}$ & $\begin{array}{l}\text { RT }=14 \\
\text { No RT }=11 \\
p=0.28\end{array}$ & - & - & Sx of brain mets \\
\hline $\begin{array}{l}\text { Flannery et al. } \\
{[18]}\end{array}$ & 2008 & $\begin{array}{l}\text { RT }=26 \\
\text { Chemo/RT } \\
=9 \\
\text { Sx }=12 \\
\text { Preop } \\
\text { Chemo + } \\
\text { Sx }=5\end{array}$ & 1 & STS & $\begin{array}{l}\text { Overall: } 18 \\
\text { Definitive tx: } \\
26.4 \\
\text { No definitive } \\
\text { tx: } 13.1 \\
p<0.0001\end{array}$ & Overall: 71.3 & Overall: 34.1 & $\begin{array}{l}\text { Overall: } 21 \\
\text { RT: } 34.6 \\
\text { No RT: } 0 \\
p<0.0001\end{array}$ & $\begin{array}{l}\text { Definitive thoracic } \\
\text { therapy } \\
\text { KPS }\end{array}$ \\
\hline $\begin{array}{l}\text { Louie et al. } \\
\text { [16] }\end{array}$ & 2009 & $\begin{array}{l}\text { Sx }=8 \\
\text { Chemo }= \\
24 \\
\text { RT }=14\end{array}$ & 1 & Sx + WBRT & $\begin{array}{l}7.8 \\
\text { Stage I/II: } \\
14.7 \\
\text { Stage III: } 7\end{array}$ & - & - & - & 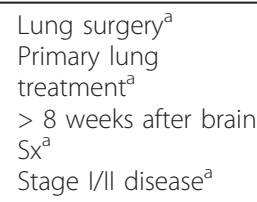 \\
\hline $\begin{array}{l}\text { Arrieta et al. } \\
\text { (present } \\
\text { series) }\end{array}$ & 2010 & $\begin{array}{l}\text { Chemo- } \\
\text { Chemo/RT } \\
=30\end{array}$ & $>1$ & WBRT & 31.8 & 71.1 & 60.2 & & $\begin{array}{l}\text { 3-year OS for N0-1 } \\
\text { was } 60 \text { vs. 24\% for } \\
\text { N2-3 }\end{array}$ \\
\hline
\end{tabular}

NSCLC: Non-small-cell lung cancer; Sx: Surgery; RT: Radiotherapy; WBRT: Whole-brain radiotherapy; STS: Stereotactic surgery; Comb: Combination; Mets: Metastasis/Metastases; Chemo: Chemotherapy; Chemo/RT: Chemo-radiotherapy; Preop: Pre-operative. a) Univariate analysis.

chemoradiotherapy of the primary lung tumor in patients with central nervous metastatic disease.

To our knowledge, this is the first time that patients with multiple synchronous brain metastases treated with WBRT have been managed with aggressive therapy for primary tumor in chest with concurrent chemoradiotherapy, showing a very long OS. Among series that evaluated surgery as local treatment for the thoracic disease, several included patients with multiple brain metastases [12,28-32]. In none of these studies was the number of brain lesions described as a factor that conferred poor prognosis.

Other prognostic factors associated with better outcomes with this definitive strategy after treatment to the brain disease are younger age $[31,33]$, early stage nodal disease [15-17,27,28,31], good performance status
[18,30-32,34], adenocarcinoma subtype [14,28,32,35], location of primary tumor, site of brain metastases, and low CEA levels $[28,36]$.

Median survival in patients treated in this series is remarkably long. One of the reasons might be that we selected patients who presented with synchronous brain tumors and did not include those with metachronous lesions, which may represent a better prognostic group. In addition, we selected patients who did not progress after induction chemotherapy to proceed with further thoracic management, in order to ensure that patients with rapid progressive metastatic disease would not be submitted to a more aggressive management instead of a palliative approach. Furthermore, the majority of patients were assessed with PET-CT at diagnosis, which reduces the likelihood of metastatic disease elsewhere, 
compared with routine evaluation with $\mathrm{CT}$ and bone scan [37]. Finally, a high proportion of patients had stage 0-1 nodal disease (53.3\%) and 0-1 ECOG grade (90\%) and with few comorbidities, which might suggest that this therapeutic approach should be reserved for otherwise healthy patients with non-bulky mediastinal lymph node involvement.

\section{Conclusion}

Patients with NSCLC and synchronous brain metastases might benefit from aggressive treatment with WBRT and concurrent chemoradiotherapy to the primary lesion, particularly in well-selected patients. The result of this study warrants a prospective trial in stage IV disease with only brain metastasis to confirm the benefit of this treatment.

\section{Acknowledgements}

Presented in part as a poster at the 14th World Conference on Lung Cancer of the International Association for the study of Lung Cancer, July 3-7, 2011 Amsterdam, The Netherlands. And will be presented as a poster presentation at the 2011 Annual Meeting of the American Society for Radiation Oncology, October 2-6, 2011 Miami, Florida.

\section{Author details}

${ }^{1}$ Clinic of Thoracic Oncology, Instituto Nacional de Cancerología (INCan), Mexico City, Mexico. ${ }^{2}$ Experimental Oncology Laboratory, INCan, Mexico City, Mexico. ${ }^{3}$ Facultad de Medicina, Universidad Nacional Autónoma de México (UNAM), Mexico City, Mexico. ${ }^{4}$ Radio-Oncology Department, INCan, Mexico City, Mexico.

\section{Authors' contributions}

OA conceived of the study, and participated in its design and coordination. CV participated in its design and drafted the manuscript. JZ performed the patient selection and analysis. MB performed the patient selection and analysis. MDM participated in patient selection, analysis and manuscript draft. DGZ participated in the manuscript draft. SM performed the statistical analysis. JG participated in its design and coordination. All authors read and approved the final manuscript.

\section{Conflict of interests}

The authors declare that they have no competing interests.

Received: 29 July 2011 Accepted: 25 November 2011 Published: 25 November 2011

\section{References}

1. Knights EM Jr: Metastatic tumors of the brain and their relation to primary and secondary pulmonary cancer. Cancer 1954, 7(2):259-65.

2. Galluzzi S, Payne PM: Brain metastases from primary bronchial carcinoma: a statistical study of 741 necropsies. Br J Cancer 1956, 10(3):408-14.

3. Newman SJ, Hansen HH: Proceedings: Frequency, diagnosis, and treatment of brain metastases in 247 consecutive patients with bronchogenic carcinoma. Cancer 1974, 33(2):492-6.

4. Sorensen JB, Hansen HH, Hansen M, Dombernowsky P: Brain metastases in adenocarcinoma of the lung: frequency, risk groups, and prognosis. $J$ Clin Oncol 1988, 6(9):1474-80.

5. Lagerwaard FJ, Levendag PC, Nowak PJ, Eijkenboom WM, Hanssens PE, Schmitz PI: Identification of prognostic factors in patients with brain metastases: a review of 1292 patients. Int J Radiat Oncol Biol Phys 1999, 43(4):795-803.

6. Schouten $L$, Rutten J, Huveneers HA, Twijnstra A: Incidence of brain metastases in a cohort of patients with carcinoma of the breast, colon, kidney, and lung and melanoma. Cancer 2002, 94(10):2698-705.
7. Patchell RA, Tibbs PA, Walsh JW, Dempsey RJ, Maruyama Y, Kryscio RJ, Markesbery WR, Macdonald JS, Young B: A randomized trial of surgery in the treatment of single metastases to the brain. N Engl J Med 1990, 322(8):494-500.

8. Noordijk EM, Vecht CJ, Haaxma-Reiche H, Padberg GW, Voormolen JH, Hoekstra FH, Tans JT, Lambooij N, Metsaars JA, Wattendorff AR, Brand R, Hermans J: The choice of treatment of single brain metastasis should be based on extracranial tumor activity and age. Int J Radiat Oncol Biol Phys 1994, 29(4):711-7.

9. Alexander E, Moriarty TM, Davis RB, Wen PY, Fine HA, Black PM, Kooy HM, Loeffler JS: Stereotactic radiosurgery for the definitive, noninvasive treatment of brain metastases. J Natl Cancer Inst 1995, 87(1):34-40.

10. Andrews DW, Scott CB, Sperduto PW, Flanders AE, Gaspar LE, Schell MC, Werner-Wasik M, Demas W, Ryu J, Bahary JP, Souhami L, Rotman M, Mehta MP, Curran WJ Jr: Whole brain radiation therapy with or without stereotactic radiosurgery boost for patients with one to three brain metastases: phase III results of the RTOG 9508 randomised trial. Lancet 2004, 363(9422):1665-72

11. Mekhail T, Sombeck M, Sollaccio R: Adjuvant whole-brain radiotherapy versus observation after radiosurgery or surgical resection of 1-3 cerebral metastases: results of the EORTC 22952-26001 study. Curr Oncol Rep 2011, 13(4):255-8.

12. Magilligan DJ Jr, Duvernoy C, Malik G, Lewis JW Jr, Knighton R, Ausman Jl: Surgical approach to lung cancer with solitary cerebral metastasis: twenty-five years' experience. Ann Thorac Surg 1986, 42(4):360-4.

13. Chidel MA, Suh JH, Greskovich JF, Kupelian PA, Barnett GH: Treatment outcome for patients with primary nonsmall-cell lung cancer and synchronous brain metastasis. Radiat Oncol Investig 1999, 7(5):313-9.

14. Bonnette P, Puyo P, Gabriel C, Giudicelli R, Regnard JF, Riquet M, Brichon PY: Surgical management of non-small cell lung cancer with synchronous brain metastases. Chest 2001, 119(5):1469-75.

15. Billing PS, Miller DL, Allen MS, Deschamps C, Trastek VF, Pairolero PC: Surgical treatment of primary lung cancer with synchronous brain metastases. J Thorac Cardiovasc Surg 2001, 122(3):548-53.

16. Louie AV, Rodrigues G, Yaremko B, Yu E, Dar AR, Dingle B, Vincent M, Sanatani M, Younus J, Malthaner R, Inculet R: Management and prognosis in synchronous solitary resected brain metastasis from non-small-cell lung cancer. Clin Lung Cancer 2009, 10(3):174-9.

17. Hu C, Chang EL, Hassenbusch SJ, Allen PK, Woo SY, Mahajan A, Komaki R, Liao Z: Nonsmall cell lung cancer presenting with synchronous solitary brain metastasis. Cancer 2006, 106(9):1998-4.

18. Flannery TW, Suntharalingam M, Regine WF, Chin LS, Krasna MJ, Shehata MK, Edelman MJ, Kremer M, Patchell RA, Kwok Y: Long-term survival in patients with synchronous, solitary brain metastasis from non-small-cell lung cancer treated with radiosurgery. Int J Radiat Oncol Biol Phys 2008, 72(1):19-23.

19. Greene FL, American Joint Committee on Cancer, American Cancer Society: AJCC Cancer Staging Manual. New York: Springer-Verlag; 62002

20. Kondziolka D, Patel A, Lunsford LD, Kassam A, Flickinger JC: Stereotactic radiosurgery plus whole brain radiotherapy versus radiotherapy alone for patients with multiple brain metastases. Int J Radiat Oncol Biol Phys 1999, 45(2):427-34

21. Burt M, Wronski M, Arbit E, Galicich JH: Resection of brain metastases from non-small-cell lung carcinoma. Results of therapy. Memorial SloanKettering Cancer Center Thoracic Surgical Staff. J Thorac Cardiovasc Surg 1992, 103(3):399-410, discussion 10-1.

22. Salvati M, Cervoni L, Tarantino R, Puzzilli F, Delfini R: Solitary cerebral metastasis as first symptom of lung cancer. Neurochirurgie 1994 40(4):256-8.

23. Modi A, Vohra HA, Weeden DF: Does surgery for primary non-small cell lung cancer and cerebral metastasis have any impact on survival? Interact Cardiovasc Thorac Surg 2009, 8(4):467-73.

24. Albain KS, Swann RS, Rusch WW, Turrisi AT, Shepherd FA, Smith C, Chen Y, Livingston RB, Feins RH, Gandara DR, Fry WA, Darling G, Johnson DH, Green MR, Miller RC, Ley J, Sause WT, Cox JD: Radiotherapy plus chemotherapy with or without surgical resection for stage III non-smallcell lung cancer: a phase III randomised controlled trial. Lancet 2009, 374(9687):379-86.

25. van Meerbeeck JP, Kramer GW, Van Schil PE, Legrand C, Smit EF, Schramel F, Tjan-Heijnen VC, Biesma B, Debruyne C, van Zandwijk N, Splinter TA, Giaccone G: Randomized controlled trial of resection versus 
radiotherapy after induction chemotherapy in stage IIIA-N2 non-smallcell lung cancer. J Nat/ Cancer Inst 2007, 99(6):442-50.

26. Ampil F, Caldito G, Milligan S, Mills G, Nanda A: The elderly with synchronous non-small cell lung cancer and solitary brain metastasis: does palliative thoracic radiotherapy have a useful role? Lung Cancer 2007, 57(1):60-5

27. Mussi A, Pistolesi M, Lucchi M, Janni A, Chella A, Parenti G, Rossi G, Angeletti CA: Resection of single brain metastasis in non-small-cell lung cancer: prognostic factors. J Thorac Cardiovasc Surg 1996, 112(1):146-53.

28. Iwasaki A, Shirakusa T, Yoshinaga Y, Enatsu S, Yamamoto M: Evaluation of the treatment of non-small cell lung cancer with brain metastasis and the role of risk score as a survival predictor. Eur J Cardiothorac Surg 2004, 26(3):488-93.

29. Wronski M, Burt M: Results and prognostic factors of surgery in the management of non-small cell lung cancer with solitary brain metastasis. Cancer 1992, 70(7):2021-3.

30. Abrahams JM, Torchia M, Putt M, Kaiser LR, Judy KD: Risk factors affecting survival after brain metastases from non-small cell lung carcinoma: a follow-up study of 70 patients. J Neurosurg 2001, 95(4):595-600.

31. Moazami N, Rice TW, Rybicki LA, Adelstein DJ, Murthy SC, DeCamp MM, Barnett GH, Chidel MA, Suh JH, Blackstone EH: Stage III non-small cell lung cancer and metachronous brain metastases. J Thorac Cardiovasc Surg 2002, 124(1):113-22.

32. Girard N, Cottin V, Tronc F, Etienne-Mastroianni B, Thivolet-Bejui F, Honnorat J, Guyotat J, Souquet PJ, Cordier JF: Chemotherapy is the cornerstone of the combined surgical treatment of lung cancer with synchronous brain metastases. Lung Cancer 2006, 53(1):51-8.

33. Wronski M, Arbit E, Burt M, Galicich JH: Survival after surgical treatment of brain metastases from lung cancer: a follow-up study of 231 patients treated between 1976 and 1991. J Neurosurg 1995, 83(4):605-16.

34. Furák J, Troján I, Szöke T, Agócs L, Csekeö A, Kas J, Svastics E, Eller J, Tiszlavicz L: Lung cancer and its operable brain metastasis: survival rate and staging problems. Ann Thorac Surg 2005, 79(1):241-7, discussion 41-7.

35. Yoshinaga Y, Enatsu S, Iwasaki A, Shirakusa T: Surgical treatment for primary non-small cell lung cancer with synchronous brain metastases. [in Japanese]. Kyobu Geka 2006, 59(1):41-5.

36. Arrieta O, Saavedra-Perez D, Kuri R, Aviles-Salas A, Martinez L, MendozaPosada D, Castillo P, Astorga A, Guzman E, De la Garza J: Brain metastasis development and poor survival associated with carcinoembryonic antigen (CEA) level in advanced non-small cell lung cancer: a prospective analysis. (Abstract). BMC Cancer 2009, 9:119.

37. Fischer B, Lassen U, Mortensen J, Fischer B, Lassen U, Mortensen J, Larsen S, Loft A, Bertelsen A, Ravn J, Clementsen P, Høgholm A, Larsen K,

Rasmussen T, Keiding S, Dirksen A, Gerke O, Skov B, Steffensen I, Hansen H, Vilmann P, Jacobsen G, Backer V, Maltbaek N, Pedersen J, Madsen H, Nielsen $H$, Højgaard L: Preoperative staging of lung cancer with combined PET-CT. N Engl J Med 2009, 361(1):32-9.

doi:10.1186/1748-717X-6-166

Cite this article as: Arrieta et al: Long-term survival in patients with non-small cell lung cancer and synchronous brain metastasis treated with whole-brain radiotherapy and thoracic chemoradiation. Radiation Oncology 2011 6:166.

\section{Submit your next manuscript to BioMed Central and take full advantage of:}

- Convenient online submission

- Thorough peer review

- No space constraints or color figure charges

- Immediate publication on acceptance

- Inclusion in PubMed, CAS, Scopus and Google Scholar

- Research which is freely available for redistribution

Submit your manuscript at www.biomedcentral.com/submit
Biomed Central 